\title{
KAJIAN VEGETASI DI KAWASAN PASCA TAMBANG MARMER KABUPATEN TIMOR TENGAH UTARA
}

\author{
Emilia Juliyanti Bria*, Remigius Binsasi** \\ * Program Studi Biologi, Fakultas Sains dan Teknologi, Universitas Timor \\ ** Program Studi Biologi, Fakultas Sains dan Teknologi, Universitas Timor \\ Correspondence Author: emiliajuliyanti@gmail.com
}

\begin{abstract}
Marble is one of the industrial materials of high economic value and very beneficial to people's lives. Therefore, many explorations are done by mining companies. Exploitation of natural resources on a large scale without regard to the carrying capacity of the environment, can lead to drastic decline in the quality of the ecosystem. This is what happened in the post-mine forest area of Oenbit Village, North Central Timor District. This study aims to identify and calculate the abundance of plants and environmental factors that affect the plants in the post-marble area of Oenbit village. The method used is quadratic / plot method. The results showed that plant species with significant values above $80.00 \%$ were Anacardium occidentale L. (125.69\%), Tamarindus indica L. (122.17\%), Tectona grandis L.f (87.32\%), and Schleichera oleosa (Lour .) Oken (82.67\%). Abiotic environmental factors measured at the study sites are soil pH, soil moisture, air temperature, air humidity and light intensity. The results of these measurements showed no significant difference.
\end{abstract}

\section{Keyword: vegetation, marble, Oenbit}

\section{INTISARI}

Marmer merupakan salah satu bahan industri yang bernilai ekonomi tinggi dan sangat bermanfaat bagi kehidupan masyarakat. Oleh karena itu, banyak eksplotasi yang dilakukan oleh perusahaan penambang. Eksploitasi sumber daya alam secara besar - besaran tanpa memperhatikan daya dukung lingkungan, dapat mengakibatkan menurunnya kualitas ekosistem secara drastis. Hal ini yang terjadi di kawasan hutan pasca tambang marmer Desa Oenbit Kabupaten Timor Tengah Utara. Penelitian ini bertujuan untuk mengidentifikasi dan menghitung kemelimpahan tumbuhan serta faktor lingkungan yang berpengaruh terhadap tumbuhan yang berada di kawasan pasca tambang marmer desa Oenbit. Metode yang digunakan adalah metode kuadrat/plot. Hasil penelitian menunjukkan bahwa spesies tumbuhan yang memiliki nilai penting diatas 80,00\% adalah berturut - turut Anacardium occidentale L. (125.69 \%), Tamarindus indica L. (122.17 \%), Tectona grandis L.f (87.32 \%), dan Schleichera oleosa (Lour.) Oken (82.67 \%). Faktor lingkungan abiotik yang diukur pada lokasi penelitian adalah $\mathrm{pH}$ tanah, kelembaban tanah, suhu udara, kelembababan udara dan intensitas cahaya. Hasil pengukuran ini tidak menunjukkan perbedaan yang signifikan.

Kata kunci: vegetasi, marmer, Oenbit 


\section{PENDAHULUAN}

Industri pertambangan saat ini sangat berkembang pesat dan hal ini menyebabkan meningkatnya jumlah permintaan dalam pemenuhan kebutuhan masyarakat. Marmer atau batu pualam merupakan salah satu bahan industri yang bernilai ekonomi tinggi. Manfaat marmer antara lain sebagai bahan dasar pembuatan berbagai macam furniture, pembersih rumah, pupuk, penetral asam, dan sumber kalsium tambahan untuk ternak. Oleh karena itu, banyak perusahaan pertambangan melakukan eksplorasi dan eksploitasi untuk mendapatkan marmer yang berkualitas.

Tambang marmer merupakan salah satu jenis pertambangan terbuka. Pada pertambangan terbuka biasanya dilakukan proses peledakan untuk membongkar batuan di dalamnya. Kandungan kimia terbesar dalam pecahan marmer adalah kalsium oksida $(\mathrm{CaO})$ yaitu sebesar $55,07 \%$ (Wihardi, dkk., 2006). Kalsium merupakan salah satu unsur essensial bagi tumbuhan. Unsur ini memiliki fungsi antara lain membentuk dinding sel yang sangat dibutuhkan dalam proses pembentukan sel baru, mendorong pembentukan buah dan biji yang sempurna, dapat menetralkan asam-asam organik yang dihasilkan pada proses metabolisme dan merangsang terbentuknya bulubulu akar (Sari, dkk., 2013).

Hutan kawasan lahan bekas marmer merupakan hutan musim yang mana vegetasi yang terdapat di dalamnya didominasi oleh jenis pohon yang menggugurkan daun di musim kering sehingga tipe ekosistem musim kering disebut juga hutan meranggas. Hutan adat di desa oenbit dijadikan salah satu lahan tambang marmer tahun sejak 2010 - 2014. Akibat dari kegiatan tersebut, kawasan hutan tersebut berubah menjadi lahan tandus. Eksploitasi sumber daya alam secara besar besaran tanpa memperhatikan daya dukung lingkungan, dapat mengakibatkan menurunnya kualitas ekosistem secara drastis (Indriyanto, 2008).

Salah satu unsur penting penyusun ekosistem hutan adalah vegetasi. Vegetasi merupakan kumpulan tumbuh - tumbuhan yang terdiri dari beberapa jenis dan hidup bersama pada suatu tempat. Distribusi, ukuran, dan perubahan populasi dalam komunitas di suatu habitat atau ekosistem disebabkan karena adanya interaksi antar faktor biotik dan faktor lingkungan (fisika kimia). Interaksi antara berbagai faktor tersebutlah yang menentukan hadir atau tidak hadirnya suatu organisme atau spesies. Bila suatu spesies hadir, maka kemelimpahan populasinya bervariasi baik pada skala ruang (tempat = spasial) maupun waktu (temporal) $($ Reyhan \& Amiraslani, 2006). Penelitian ini bertujuan untuk mengidentifikasi dan menghitung kemelimpahan tumbuhan serta faktor lingkungan yang berpengaruh terhadap tumbuhan yang berada di kawasan pasca tambang marmer desa Oenbit.

\section{METODE PENELITIAN}

Penelitian ini dilaksanakan di kawasan pasca tambang marmer Desa Oenbit Kecamatan Insana Kabupaten Timor Tengah Utara yang berada pada wilayah dengan ketinggian $500 \mathrm{~m}$ dari atas permukaan laut. Obyek pnelitian ini adalah vegetasi. Tahapan penelitian adalah melakukan studi pustaka, survei lokasi di kawasan pasca tambang marmer untuk mendapatkan informasi mengenai vegetasi dengan melakukan wawancara terhadap penduduk setempat (Kepala Desa dan para tua adat) perihal proses awal pelaksanaan penambangan marmer oleh pihak penambang (PT. Elgary Resources Indonesia- ERI).

Penentuan titik sampling/stasiun dilakukan dengan melihat penyebaran tumbuhan di sekitar kawasan pasca tambang marmer dengan membuat plot di setiap stasiun (4 stasiun) untuk mengetahui seberapa luasan vegetasi di kawasan pasca tambang marmer tersebut dan area mana yang akan di cuplik. Pengambilan data vegetasi menggunakan metode kuadrat/plot berukuran $20 \mathrm{~m}$ x $20 \mathrm{~m}=400 \mathrm{~m}^{2}$ secara acak (proporsional random sampling) berdasarkan titik sampilng atau stasiun. Jumlah stasiun dibagi menjadi 4 stasiun dengan jumlah plot secara keseluruhan sebanyak 20 plot dengan masing-masing stasiun terdiri dari 5 plot. Selain itu, dilakukan pengukuran faktor fisiko kimia pada setiap plot pengamatan masing-masing stasiun. Data vegetasi dianalisis untuk melihat densitas, frekuensi, luas basal area, dan nilai penting. 


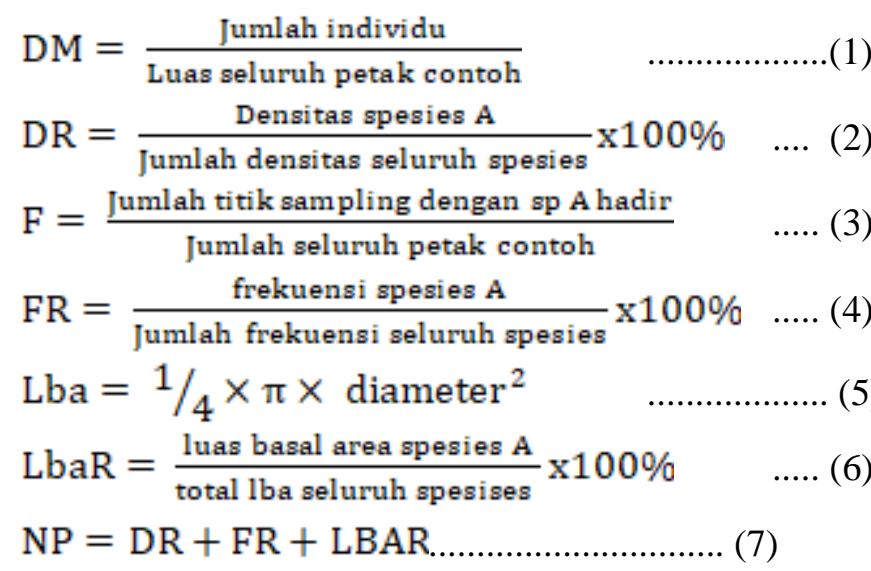

Keterangan: DM: densitas mutlak, DR: densitas relatif, F: frekuansi, FR: frekuensi relatif, Lba: luas basal area, LbaR: luas basal area relatif, NP: nilai penting.

\section{HASIL DAN ANALISA (11 PT)}

3.1. Analisis Vegetasi

Vegetasi mempunyai peranan penting karena berfungsi sebagai pengatur hidrologi, pencegah banjir, serta mengatasi kekeringan. Hasil analisis vegetasi yang diperoleh berupa jumlah individu, jumlah spesies, dan diameter batang. Data yang diperoleh selanjutnya dilakukan perhitungan densitas relatif (DR), frekuensi relatif (FR), luas basal area (LBA) relatif, dan indeks nilai penting (INP) (Gambar 1).

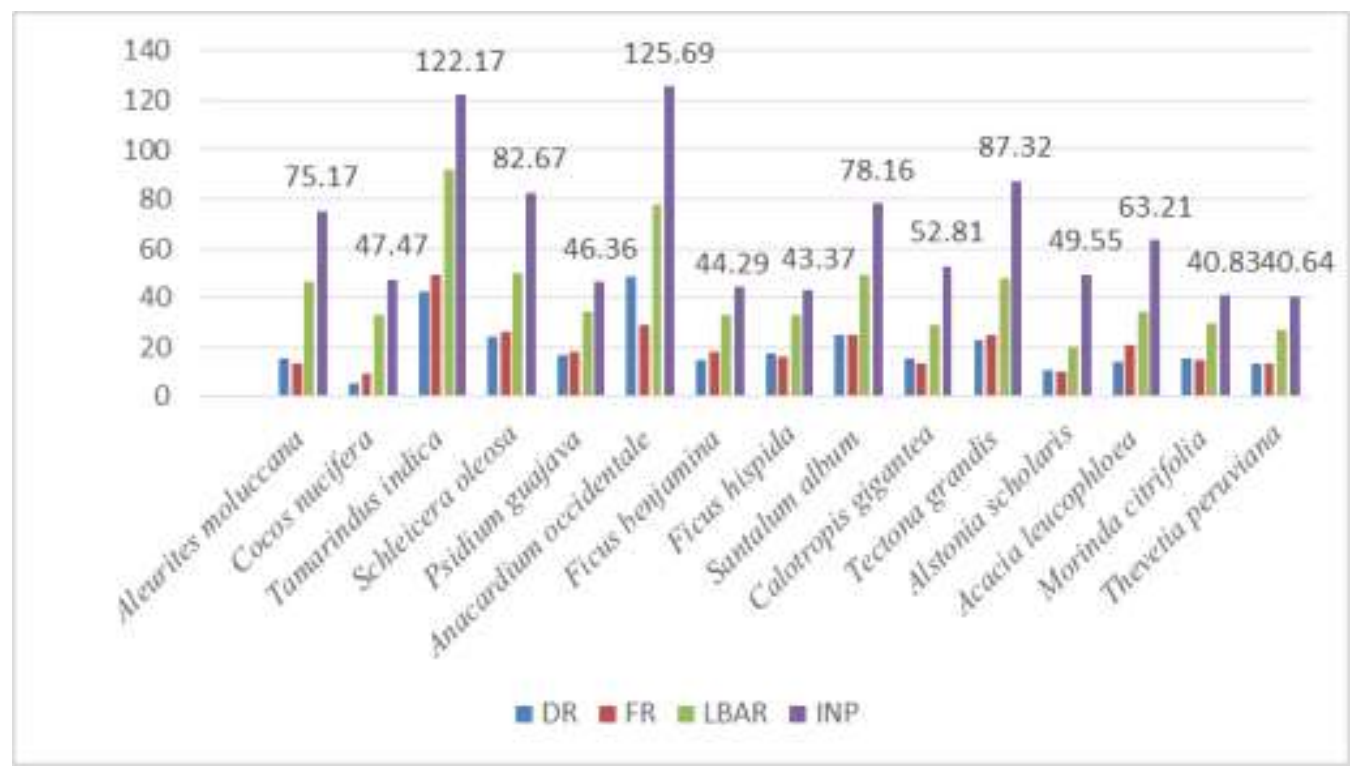

Gambar 1. Perhitungan indeks nilai penting (INP) spesies penyusun vegetasi di kawasan bekas tambang marmer Desa Oenbit, Kabupaten Timor Tengah Utara

Hasil penelitian menunjukkan setidaknya tercatat 15 spesies vegetasi dari 11 famili yang dijumpai di sekitar kawasan pasca tambang marmer Desa Oenbit Kecamatan Insana Kabupaten TTU (Tabel 1). Sebagian besar vegetasi tersebut memiliki diameter batang lebih dari $20 \mathrm{~cm}$. Kelima belas spesies yang ditemukan, didominasi oleh famili Apocynaceae (3 spesies). Tiga spesies tersebut antara lain Alstonia scholaris (L.) R. Br, Calotropis gigantea (L.) W.T.Aiton dan Thevetia peruviana (Pers.) K. Schum. Kelompok spesies selain famili Apocynaceae, berturut turut adalah Fabaceae (2 spesies), Moraceae (2 spesies), Euphorbiaceae, Arecaceae, Sapindaceae, 
Myrtaceae, Anacardiaceae, Santalaceae, Verbenaceae, Rubiaceae yang masing - masing satu spesies.

Tabel 1. Spesies Tumbuhan Penyusun Vegetasi Di Kawasan Pasca Tambang Marmer Desa Oenbit Kabupaten Timor Tengah Utara

\begin{tabular}{|c|c|c|c|}
\hline No & Suku & Spesies & Nama Lokal \\
\hline \multirow[t]{3}{*}{1} & Apocynaceae & Alstonia scholaris (L.) R.Br & Pule \\
\hline & & Calotropis gigantea (L.) W.T. Aiton & Biduri \\
\hline & & Thevetia peruviana (Pers) K. Schum & Pohon racun \\
\hline \multirow{2}{*}{2} & Fabaceae & Acacia leucophloea (Roxb.) Willd & Kabesak \\
\hline & & Tamarindus indica $\mathrm{L}$. & Asam \\
\hline \multirow[t]{2}{*}{3} & Moraceae & Ficus hispida L.f & \\
\hline & & Ficus benjamina $\mathrm{L}$. & Beringin \\
\hline 4 & Euphorbiaceae & Aleurites moluccanus (L.) Willd & Kemiri \\
\hline 5 & Arecaceae & Cocos nucifera $\mathrm{L}$. & Kelapa \\
\hline 6 & Sapindaceae & Schleichera oleosa (Lour.) Oken & Kusambi \\
\hline 7 & Myrtaceae & Psidium guajava $\mathrm{L}$. & Jambu biji \\
\hline 8 & Anacardiaceae & Anacardium occidentale L. & Jambu mente \\
\hline 9 & Santalaceae & Santalum album L. & Cendana \\
\hline 10 & Verbenaceae & Tectona grandis $\mathrm{L} . \mathrm{f}$ & Jati \\
\hline 11 & Rubiaceae & Morinda citrifolia $\mathrm{L}$. & Mengkudu \\
\hline
\end{tabular}

Berdasarkan tabel di atas, kelompok tumbuhan yang mendominasi area pasca tambang marmer adalah famili Apocynaceae, Fabaceae, dan Moraceae. Famili Apocynaceae merupakan tumbuhan berupa pohon atau semak, tegak atau memanjat. Jarang sekali berupa herba. Kelenjar getah merupakan ciri umum dari kelompok tumbuhan ini. Daerah peyebaran tumbuhan ini dimulai dari daerah tropis ke daerah sub-tropis. Bahkan ada beberapa marga yang menempati zona sedang. Buah kelompok tumbuhan ini berupa folikel, kapsul atau buah beri. Suku ini meliputi 180-200 marga dengan 1500-2000 jenis. Beberapa jenis dari suku ini mempunyai peranan penting untuk pembuatan obat-obatan dan tanaman hias.

Famili fabaceae dikenal sebagai kelompok tumbuhan polong - polongan. Kelompok ini merupakan famili terbesar ketiga setelah suku anggrek - anggrekan dan suku aster. Kelompok tumbuhan ini dikenal dalam proses fiksasi $\mathrm{N}_{2}$. Namun, spesies yang ditemukan dalam penelitian ini memiliki efektifitas bintil akar yang rendah dalam mengfiksasi $\mathrm{N}_{2}$ dari lingkungan. Walaupun demikian, kemampuan adaptasi terhadap daerah kering dan minim unsur hara sangat tinggi.

Moraceae termasuk famili tumbuhan yang tersebar di daerah hutan tropis sampai subtropik. Tumbuhan yang temasuk dalam suku ini merupakan tumbuhan yang berbatang kayu, dan menghasilkan getah. Dalam penelitian ini hanya genus Ficus yang ditemukan. Ficus merupakan salah satu genus terbesar dari tanaman obat dengan jumlah spesies sekitar 750 spesies tanaman kayu, pohon, dan semak-semak, tersebar di daerah subtropis dan tropis di seluruh dunia. Habitus Ficus berupa tumbuhan tinggi yang dapat tumbuh baik di dataran rendah maupun dataran tinggi dan terdapat di seluruh daerah di Indonesia. Kelompok tumbuhan ini dapat tumbuh mencapai ketinggian sampai $50 \mathrm{~m}$ dpl. Selain itu, genus ini diketahui mengandung berbagai macam senyawa kimia, diantaranya senyawa steroid dan turunannya, terpenoid, alkaloid, senyawa turunan asetofenon, turunan flavonoid, dan senyawa alifatik rantai panjang.

\subsection{Spesies Tumbuhan Dominan}

Berdasarkan perhitungan INP (Gambar 1), spesies yang memiliki INP diatas 80,00\% adalah A. occidentale (125.69 \%), T. indica (122.17\%), T. grandis (87.32\%), dan S. oleosa (82.67

ISSN Print $\quad: 1979-7141$ 
\%). Perbedaan tersebut dipengaruhi oleh faktor-faktor lingkungan sebagai salah satu faktor pembatas akan hadirnya spesies dalam suatu wilayah komunitas hutan.

A. occidentale merupakan tumbuhan yang dapat beradaptasi dengan kondisi yang sangat kering asalkan sistem akar yang luas memiliki akses terhadap kelembaban tanah. Hal tersebut juga harus didukung dengan suhu tinggi. Buah tumbuhan ini akan baik jika hujan tidak melimpah saat berbunga dan jika kacangnya matang dalam periode kering.

Bertahan dan tumbuh dalam berbagai kondisi iklim dan edafik merupakan keunikan dari $T$. grandis Pertumbuhannya paling baik di iklim tropis yang hangat dan lembab dengan perbedaan yang signifikan antara musim kering dan musim hujan. Tumbuhan ini adalah spesies perintis, tetapi dengan rentang umur yang panjang. Berbeda dengan spesies perintis lainnya, $T$. grandis mampu bertahan dan mendominasi dan secara alami beregenerasi menuju fase klimaks suksesi di sebagian besar wilayah alamnya.

T. indica tumbuh dengan baik di berbagai kondisi tanah dan iklim, terjadi di dataran rendah, padang rumput dan semak, sering dikaitkan dengan gundukan rayap. Tumbuhan ini lebih menyukai daerah semi gersang dan padang rumput berhutan, dan juga dapat ditemukan tumbuh di sepanjang aliran sungai dan sungai. Sistem akarnya yang luas berkontribusi pada sistemnya ketahanan terhadap kekeringan dan angin. Periode berbuah paling baik pada musim kemarau yang panjang.

S. oleosa merupakan tumbuhan yang beradaptasi baik pada daerah yang memiliki musim kering dengan curah hujan $750-2500 \mathrm{~mm}$ per tahun. Selain itu tumbuhan ini juga memiliki toleransi suhu maksmimum mutlak $35-37.5^{\circ} \mathrm{C}$ dan suhu minimum $-2.5^{\circ} \mathrm{C}$. Tumbuhan ini dapat ditemukan pada daerah dataran rendah hingga 900 - $1200 \mathrm{~m}$ dpl.dapat tumbuh baik pada wilayah yang beragam antara lain berbatu, kering atau liat dan nilai $\mathrm{pH}$-nya sedikit asam.

\subsection{Faktor Lingkungan Terukur di Wilayah Penelitian}

Selain pengukuran vegetasi, dilakukan juga pengukuran faktor lingkungan untuk mengetahui pengaruh pertumbuhan dan perkembangan vegetasi dalam suatu wilayah. Suatu vegetasi terbentuk oleh adanya kehadiran dan interaksi dari beberapa jenis tumbuhan di dalamnya. Hal ini disebabkan karena banyak variabel berbagai faktor, baik biotik dan fisiko kimia yang saling berinteraksi. Interaksi tersebut yang menentukan hadir atau tidak hadirnya suatu organisme atau spesies (Reyhan \& Amiraslani, 2006). Pengaruh faktor-faktor lingkungan terhadap komunitas tumbuhan akan berbeda pada waktu dan wilayah yang berbeda pula. Faktor-faktor lingkungan abiotik yang berhubungan dengan pertumbuhan dan perkembangan vegetasi antara lain: $\mathrm{pH}$ tanah, kelembaban tanah, suhu udara, kelembababan udara dan intensitas cahaya.

Dalam penelitian ini, hasil pengukuran faktor lingkungan tidak menunjukkan perbedaan yang signifikan antar satu stasiun dengan stasiun lain. Hasil pengukuran nilai derajat keasaman ( $\mathrm{pH}$ tanah) rata-rata 4,2 - 4,8 dan nilai kelembaban tanah berkisar dari $65 \%-78 \%$. Hal ini menunjukkan bahwa $\mathrm{pH}$ tanah di lokasi penelitian tergolong masam. Menurut West (2010), $\mathrm{pH}$ tanah merupakan salah satu faktor penting yang dapat menentukan kesuburan tanah. Pada $\mathrm{pH}<4.0$, $>10.0$ akan mengakibatkan kerusakan pada tanaman dan kemungkinan timbulnya keracunan pada $\mathrm{pH}$ rendah oleh unsur kimia. Tanah asam umumnya menghambat pertumbuhan akibat rendahnya ketersediaan unsur hara fosfor dan nitrogen (Kidd \& Proctor, 2001). Kelembaban tanah berkaitan dengan kandungan air dalam tanah dan pengaturan cahaya yang berhubungan dengan naungan untuk tumbuhan. Klink \& Willmott (1994) menyatakan bahwa kelembaban tanah dapat mempengaruhi proses hidrologis suatu wilayah. Kelembaban tanah berkaitan dengan ketersediaan air bagi tumbuhan. Ketersediaan air bagi tumbuhan secara langsung mempengaruhi proses evapotranspirasi, yang dapat berlangsung jika tumbuhan memperoleh suplai air yang cukup.

Hasil pengukuran nilai suhu udara berkisar dari $30{ }^{\circ} \mathrm{C}-40{ }^{\circ} \mathrm{C}$. Tingginya suhu udara di sekitar kawasan pasca tambang marmer Desa Oenbit Kecamatan Insana Kabupaten Timor Tengah Utara ditentukan oleh radiasi matahari, kerapatan tanaman, distribusi cahaya dalam tajuk tanaman dan kandungan lengas tanah. Selain itu, suhu atau temperatur udara di sekitar vegetasi sangat 
mempengaruhi pertumbuhan dan perkembangan tanaman (Sudaryono, 2004). Hasil penelitian menunjukkan bahwa nilai kelembaban udara di sekitar lokasi penelitian adalah sangat rendah, berkisar dari $20 \%$ - $35 \%$. Kerapatan tajuk atau kanopi pohon sangat berpengaruh terhadap kelembaban udara. Hal ini sangat berkaitan dengan habitus spesies - spesies yang dominan di daerah penelitian, di mana spesies - spesies tersebut memiliki kerapatan tajuk yang kecil. Kelembaban udara dapat memengaruhi proses hidrologis yang dialami oleh tumbuhan. Peningkatan kelembaban udara disekeliling daun mengakibatkan penurunan tekanan uap diantara daun dan udara di sekitarnya. Hal ini mengakibatkan penurunan laju transpirasi (Sudaryono 2004). Secara keseluruhan hasil pengukuran nilai intensitas cahaya pada masing - masing stasiun atau titik sampling 978 - $1200 \mathrm{~cd}$. Hasil ini menunjukkan bahwa cuaca sangat panas. Cahaya matahari memiliki pengaruh yang sangat besar terhadap tumbuhan dan makhluk hidup lain. Cahaya berpengaruh terhadap pertumbuhan setiap organ keseluruhan tubuh tumbuhan secara langsung. Perubahan intensitas cahaya matahari berpengaruh terhadap kelembaban udara yang dapat mengakibatkan kekeringan pada tumbuhan (Sudaryono, 2004).

\section{KESIMPULAN (11 PT)}

Berdasarkan data dan pembahasan di atas, dapat disimpulkan bahwa

a. Vegetasi di kawasan pasca tambang marmer di Desa Oenbit Kabupaten Timor Tengah Utara terdiri atas 15 spesies dan 11 Famili.

b. Spesies tumbuhan dominan yang memiliki nilai penting di atas 80 adalah Anacardium occidentale L. (mete), Tectona grandis L. F (jati), Tamarindus indica L. (asam), dan Schleichera oleosa (Lour.) Oken (kesambi).

c. Faktor lingkungan antara lain $\mathrm{pH}$ tanah, kelembaban tanah, suhu udara, kelembababan udara dan intensitas cahaya tidak menunjukkan perbedaan yang signifikan diantara stasiun yang dicuplik.

\section{ACKNOWLEDGEMENTS}

Terima kasih kepada pihak pemerintah khususnya perangkat Desa Oenbit Kecamatan Insana Kabupaten Timor Tengah Utara yang memberikat izin kepada peneliti untuk melakukan penelitian di Kawasan Hutan Pasca Tambang Marmer. 


\section{DAFTAR PUSTAKA}

Indriyanto. 2008. Ekologi Hutan. Jakarta (ID): PT Bumi Aksara

Kartasapoetra. A. G., M. M. Sutedjo. 2010. Teknologi Konservasi Tanah dan Air. Rineka Cipta. Jakarta.

Klink, K., and Willmott, C.J. 1994. Influence of Soil Moisture and Surface Roughness Heterogenity on Modeled Climate. Climate Research. 4:105-118.

Reyhan, M.K., and Amiraslani, F. 2006. Studying the Relationship Between Vegetation and Physico-Chemical Properties of Soil, Case Study: Tabas Region, Iran. Pakistan Journal of Nutrition. 5 (2): 169-171.

Sari, D.P., Ginting, Y. C, Pangaribuan, D. 2013. Pengaruh Konsentrasi Kalsium Terhadap Pertumbuhan dan Produksi Dua Varietas Tanaman Melon (Cucumis melo L.) pada Sistem Hidroponik Media Padat. Jurnal Agrotropika 18(1): 29-33

Wihardi, M. Tjaronge., Parung, Herman., Siswanto, Kenedi., Dalle, Ambo., Pecahan Marmer Sebagai Pengganti Parsial Agregat Kasar Self Compacting Concrete (SCC), Jurnal Desain dan Konstruksi, Vol. 5 No.1, 2006, pp, 3.

Sudaryono. 2004. Pengaruh Naungan Terhadap Perubahan Iklim Mikro pada Budidaya Tanaman Tembakau Rakyat. Jurnal teknik Lingkungan. 5(1): 56-60

West, J. 2010. Soil Fertility Relationship to Forage Quality. (http://utm.edu/.../Jeremy \% 2520 West.pdf), Diakses pada tanggal 21 April 2016.

Petra S. Kidd, P.S. \& Proctor, J. .Why plants grow poorly on very acid soils: are ecologists missing the obvious?.Journal of Experimental Botany, Volume 52, Issue 357, 15 April 2001, Pages 791-799 